\title{
THE INFLUENCE OF PEER TUTORING MODEL ON THE PROBLEM-SOLVING UNDERSTANDING AND COMMUNICATION SKILLS OF EIGHT GRADE JUNIOR HIGH SCHOOL STUDENTS
}

\author{
Teguh Rizki Andriana ${ }^{1}$, Jozua Sabandar ${ }^{2}$, Mumun Syaban ${ }^{3}$ \\ ${ }^{1,2,3}$ Faculty of Post-Graduate Studies, IKIP Siliwangi, Cimahi, West Java, Indonesia \\ ${ }^{1}$ teguhrizki90@gmail.com, ${ }^{2}$ jsabandar@yahoo.com, ${ }^{3}$ mumunsyaban58@gmail.com
}

Received: Aug 8 ${ }^{\text {th }}, 2018$; Accepted: Des $27^{\text {st }}, 2018$

\begin{abstract}
Various efforts to develop education which related to quality of education were overall implemented by the government to enhance quality of education. The implementation of compatible method was an effort to improve learning achievement and accomplish learning goals. Peer tutoring is a group of students who have completed learning material then provide assistance for others who got difficulty in understanding the material. From the research result were obtained, (1) Sig. 0,011 = Ho was rejected means there was difference in students learning result in mathematic lesson by using peer tutoring method compare with conventional learning method; (2) Sig. 0,002 = Ho was rejected means there was difference in problem solving communication skill in mathematic lesson by using peer tutoring method compare with conventional learning method; (3) Sig. 0,043 = Ho was rejected means there was difference in problem solving comprehension skill in mathematic lesson by using peer tutoring method compare with conventional learning method. From the data, it can be concluded that students learning result using peer tutoring method was more effective. It was because, this method demanded students to be more active in learning process either individual or overall.
\end{abstract}

Keywords: Peer Tutoring, Understanding, Communication, Junior High School.

\begin{abstract}
Abstrak
Berbagai upaya untuk mengembangkan pendidikan yang terkait dengan kualitas pendidikan secara keseluruhan dilaksanakan oleh pemerintah untuk meningkatkan kualitas pendidikan. Implementasi metode yang kompatibel adalah upaya untuk meningkatkan prestasi belajar dan mencapai tujuan pembelajaran. Tutor sebaya adalah sekelompok siswa yang telah menyelesaikan materi pembelajaran kemudian memberikan bantuan bagi orang lain yang mengalami kesulitan dalam memahami materi. Dari hasil penelitian diperoleh, (1) Sig. 0,011 = Ho ditolak artinya ada perbedaan hasil belajar siswa pada pembelajaran matematika dengan menggunakan metode turor sebaya dibandingkan dengan metode pembelajaran konvensional; (2) Sig. 0,002 = Ho ditolak artinya ada perbedaan keterampilan komunikasi pemecahan masalah dalam pembelajaran matematika dengan menggunakan metode tutor sebaya dibandingkan dengan metode pembelajaran konvensional; (3) Sig. 0,043 = Ho ditolak artinya ada perbedaan keterampilan pemahaman pemecahan masalah dalam pembelajaran matematika dengan menggunakan metode tutor sebaya dibandingkan dengan metode pembelajaran konvensional. Dari data tersebut, dapat disimpulkan bahwa hasil belajar siswa menggunakan metode tutor sebaya lebih efektif. Itu karena, metode ini menuntut siswa untuk lebih aktif dalam proses pembelajaran baik secara individu maupun keseluruhan.
\end{abstract}

Kata kunci: Tutor Sebaya, Pengertian, Komunikasi, SMP. 
How to Cite: Andriana, T. R., Sabandar, J., \& Syaban, M. (2018). The Influence of Peer Tutoring Model on the Problem-Solving Understanding and Communication Skills of Eight Grade Junior High School Students. JIML, X (X), XX-XX.

\section{INTRODUCTION}

Conventional learning which is still predominantly implemented in mathematics teaching and learning in Indonesian schools has not successfully made students understand well what they learn because students are forced to receive knowledge from the teacher without getting the meaning of the knowledge they have gained (Baswedan, 2014). Applying the appropriate method is one of the efforts to improve learning achievements and attain learning objectives. Peer tutoring is the appropriate learning model to solve the problem because it can help students to find and understand difficult concepts more easily by discussing the concepts with their peers (Hamalik, 2007). Students regularly work in groups to help each other solve complex problems. The nature of social relationship and the use of peer groups become key aspects in learning (Arjanggi \& Supriatin, 2010).

The researchers would like to specifically investigate and find whether there are differences in learning outcomes, problem-solving communication, and problem-solving understanding skills of students in mathematics learning with peer tutoring model compared to conventional learning model. Based on the description of the theoretical bases, the authors propose a research hypothesis that there are differences in learning outcomes, problem-solving communication skills, and problem-solving understanding skills between students learning mathematics with peer tutoring model and those with conventional learning model.

Peer tutoring is a learning model to help students with learning difficulties; students who can understand the learning materials more quickly can teach those who have not understood the materials, so that clever students can be facilitators or good sources of learning for their friends (Rahayu, 2010). Peer tutoring is a group of students who have thoroughly understood the lesson materials and provide assistance to students who have difficulty in understanding the lesson materials being studied. One or more students are appointed by the teacher to assist the teacher in tutoring the classmates (Nadhifah, 2011).

Conceptual understanding is the competence exhibited by students in understanding concepts and in performing the procedures (algorithm) flexibly, accurately, efficiently and precisely. According to Riley, Greeno, and Heller (Baroody, 1993: 2-8) the actual problem solving begins with the understanding of the problem, followed by the establishment of a mental representation appropriate to the problem. Clearly, the greater the conceptual understanding of a child, the greater the likelihood that the child can build a mental representation appropriate to the problem. The resulting changes of the process can be demonstrated in various forms, such as in knowledge, understanding, abilities, skills, as well as changes in other aspects that exist in the learning individual (Baroody, 1993 in Murni, \& Khotimah, 2013).

According to Jean Piaget, human beings grow, adapt, and change through physical development, personality development, socio-emotional development, and cognitive development. He further explained that learning activity focuses a child's attention on his/her thinking or mental process - not merely on the outcomes, prioritizes the role of the learner in the learning activities, and understands individual differences in terms of their development. David Ausubel's theory of learning emphasizes the importance of the learner's ability to associate new experiences, phenomena, and facts into the already established systems of 
understanding. Thus, it is expected that learners play an active role in the learning process. Meanwhile, rote learning is needed to obtain new information, such as meaning. Lev Semyonovich Vigotsky's theory stresses the sociocultural nature of learning, particularly social interaction, i.e., the interaction of individuals with others is the most important factor that encourages or triggers a person's cognitive development.

\section{METHOD}

In this research, the researchers selected a finite population. This is so because this research consists of elements with a certain number. The population included all eighth grade students of state junior high schools.

The sample was taken with "purposive sampling" technique, that is sample determination technique based on certain criteria. In this research, the researchers took samples from all students of class VIII-B as the experimental class and class VIII-C as the control class with the same number of students, namely 28 .

In this research, pretest was administered before treatment, followed by a post-test. The treatment results can thus be measured more accurately, as the learners' situations are compared before and after the treatment. The design used in this research was the two group pattern (two-group-pretest-posttest) design with a chart. The research design is as follows:

Notes:

$\mathrm{R}_{\mathrm{I}}$ : Experimental Class

$\mathrm{R}_{2}$ : Control Class

\begin{tabular}{|llll|}
\hline $\mathbf{R}_{\mathrm{I}}$ & $\mathbf{O}_{1}$ & $\mathbf{X}$ & $\mathbf{O}_{2}$ \\
$\mathbf{R}_{2}$ & $\mathbf{O}_{3}$ & & $\mathbf{O}_{4}$ \\
\hline
\end{tabular}

$\mathrm{X}$ : Treatment given with the peer tutoring method

$\mathrm{O}_{1}$ : A test for the experimental class before treatment to see problem-solving understanding and communication skills.

$\mathrm{O}_{2}$ : A test for the experimental class after treatment to see problem-solving understanding and communication skills.

$\mathrm{O}_{3}$ : A test for the control class before treatment to see problem-solving understanding and communication skills.

$\mathrm{O}_{4}$ : A test for the control class after treatment to see problem-solving understanding and communication skills

\section{RESULTS AND DISCUSSION}

The collection of data on learning (treatment) outcomes began with administering pretests to the two groups, namely the experimental class (VIII-B) and control class (VIII-C). After all the sub-topics or materials were completed, the two groups were given final tests (posttests) to see their learning outcomes after the lessons (treatments). Meanwhile, the data of students' interest were collected through a questionnaire filled out after the treatment. The following are results of the research: 
348 Andriana, Sabandar \& Syaban, The Influence of Peer Tutoring Model on the Problem-Solving

Understanding and Communication Skills of Eight Grade Junior High School Students

Table 1. Corelation between Peer Tutoring Model and Conventional Learning Model Independent Samples Test

\begin{tabular}{|c|c|c|c|c|c|c|c|c|c|c|}
\hline \multirow{4}{*}{ VARIABEL } & \multirow{2}{*}{\multicolumn{3}{|c|}{$\begin{array}{c}\text { Levene's Test for } \\
\text { Equality of Variances }\end{array}$}} & \multirow{2}{*}{\multicolumn{7}{|c|}{ t-test for Equality of Means }} \\
\hline & & & & & & & & & & \\
\hline & \multirow[t]{2}{*}{$\begin{array}{c}\text { Equal } \\
\text { variances }\end{array}$} & \multirow[t]{2}{*}{$\mathbf{F}$} & \multirow[t]{2}{*}{ Sig. } & \multirow[t]{2}{*}{$\mathbf{t}$} & \multirow[t]{2}{*}{ df } & \multirow[t]{2}{*}{$\begin{array}{l}\text { Sig. } \\
(2- \\
\text { tailed })\end{array}$} & \multirow[t]{2}{*}{$\begin{array}{c}\text { Mean } \\
\text { Difference }\end{array}$} & \multirow[t]{2}{*}{$\begin{array}{l}\text { Std. Error } \\
\text { Difference }\end{array}$} & \multicolumn{2}{|c|}{$\begin{array}{l}\text { 95\% Confidence } \\
\text { Interval of the } \\
\text { Difference }\end{array}$} \\
\hline & & & & & & & & & Lower & Upper \\
\hline \multirow{2}{*}{$\begin{array}{l}\text { Peer Tutoring } \\
\text { Model Vs } \\
\text { Conventional } \\
\text { Learning Model }\end{array}$} & Assumed & $\begin{array}{c}1.27 \\
2\end{array}$ & 0.264 & 2.636 & 58 & 0,011 & 7.853 & 2.980 & 1.889 & 13.818 \\
\hline & $\begin{array}{l}\text { Not } \\
\text { Assumed }\end{array}$ & & & 2.636 & 55.894 & 0,011 & 7.853 & 2.980 & 1.884 & 13.823 \\
\hline \multirow{2}{*}{$\begin{array}{l}\text { Communication } \\
\text { Skills }\end{array}$} & Assumed & $\begin{array}{c}0.00 \\
0\end{array}$ & 1,000 & 3.270 & 58 & 0,002 & 2,0000 & 0.6116 & 0,7758 & 3.2242 \\
\hline & $\begin{array}{l}\text { Not } \\
\text { Assumed }\end{array}$ & & & 3.270 & 58.000 & 0,002 & 2,0000 & 0.6116 & 0,7758 & 3.2242 \\
\hline \multirow{2}{*}{$\begin{array}{l}\text { Understanding } \\
\text { Skills }\end{array}$} & Assumed & $\begin{array}{c}0.00 \\
1\end{array}$ & 0.976 & 2.073 & 58 & 0,043 & 1.2667 & 0.6111 & 0.0435 & 2.4899 \\
\hline & $\begin{array}{l}\text { Not } \\
\text { Assumed }\end{array}$ & & & 2.073 & 58.000 & 0,043 & 1.2667 & 0.6111 & 0.0435 & 2.4899 \\
\hline
\end{tabular}

From the results of data processing with SPSS to find differences in students' learning outcomes in mathematics between those learning with peer tutoring model and those with the conventional learning model, a sig. value of 0.011 was obtained. Consequently, Ho was rejected, meaning that there were differences in the learning outcomes of mathematics between students learning with peer tutoring model and those with the conventional learning model.

Based on the results of data processing with SPSS to find differences in problem-solving communication skills between students who learned mathematics with peer tutoring model and those with the conventional learning model, a sig. value of 0.002 was obtained, so that Ho was rejected, i.e. there were differences in problem-solving communication skills between students who attended peer tutoring model in learning mathematics and those attended the class with the conventional learning model.

Data obtained from the results of processing with SPSS on the differences in problem-solving understanding skills between students who learned mathematics with peer tutoring model and those with the conventional learning model show a sig. value pf 0.043 , which means that Ho was rejected. Hence, there were differences in problem-solving understanding skills between students who attended peer tutoring for mathematics learning and those with the conventional learning model.

\section{CONCLUSION}

Based on the results of research on the influence of mathematics peer tutoring model on the problem-solving understanding and communication skills of the eight grade junior high school students, the following conclusions are drawn:

There were differences in mathematics learning outcomes between students learning with peer tutoring model and those with the conventional learning model. 
There were differences in problem-solving communication skills between students who attended peer tutoring session of mathematics learning and those with the conventional learning model.

There were differences in problem-solving understanding skills between students who attended the mathematics peer tutoring session and those learning with the conventional learning model.

\section{REFERENCES}

Arjanggi, R., \& Supriatin, T. (2010). Metode Pembelajaran Tutor Teman Sebaya Mengingkatkan Hasil Belajar Berdasar Regulasi Diri. Jurnal Makara, Sosial Humaniora, 14(2), 91-97.

Baroody, (1993:2-8), Murni, E. N., \& Khotimah, R. P. (2013). Opimalisasi Stategi Pembelajaran Siklus Untuk Meningkatkan Kemandirian Belajar Matematika. Universitas Sebelas Maret Surakarta.

Baswedan, A. R. (2014). Gawat Darurat Pendidikan di Indonesia. Jakarta: Kemendikbud.

Hamalik, O. (2007). Proses Belajar Mengajar. Jakarta: Bumi Aksara.

Nadhifah, A. (2011). Pengaruh Keaktifan Peserta Didik Dalam Model Tutor Sebaya Terhadap Hasil Belajar Pada Materi System Pernapasan Manusia. Skipsi pada Fakultas Tarbiyah IAIN Walisongo Semarang.

Rahayu, D. P. (2010). Pengaruh Model Pembelajaran Tutor Sebaya Tipe Peer Assisted Learning Stategis (PALS).

Arjanggi, R., \& Supriatin, T. (2010). Metode Pembelajaran Tutor Teman Sebaya Mengingkatkan Hasil Belajar Berdasar Regulasi Diri. Jurnal Makara, Sosial Humaniora, 14(2), 91-97.

Baroody, (1993:2-8), Murni, E. N., \& Khotimah, R. P. (2013). Opimalisasi Stategi Pembelajaran Siklus Untuk Meningkatkan Kemandirian Belajar Matematika. Universitas Sebelas Maret Surakarta.

Baswedan, A. R. (2014). Gawat Darurat Pendidikan di Indonesia. Jakarta: Kemendikbud.

Hamalik, O. (2007). Proses Belajar Mengajar. Jakarta: Bumi Aksara.

Nadhifah, A. (2011). Pengaruh Keaktifan Peserta Didik Dalam Model Tutor Sebaya Terhadap Hasil Belajar Pada Materi System Pernapasan Manusia. Skipsi pada Fakultas Tarbiyah IAIN Walisongo Semarang.

Rahayu, D. P. (2010). Pengaruh Model Pembelajaran Tutor Sebaya Tipe Peer Assisted Learning Stategis (PALS). 